\title{
Timber-based agrisilviculture improves financial viability of hardwood plantations: A case study from Panama
}

Authors: $\quad$ Carola Paul ${ }^{*}$ (carola.paul@tum.de)

Verena C. Griess ${ }^{2}$ (verena.griess@ubc.ca)

Nirit Havardi-Burger ${ }^{1}$ (nirithvardi@ $@$ hotmail.com)

Michael Weber ${ }^{1}$ (m.weber@forst.wzw.tum.de)

* Corresponding author

1) Institute of Silviculture, TUM School of Life Sciences Weihenstephan,

Technische Universitaet Muenchen, Hans-Carl-von-Carlowitz-Platz 2, 85354

Freising, Germany

2) Department of Forest Resources Management, Faculty of Forestry, University of British Columbia, Forest Sciences Center, 2211-2424 Main Mall, Vancouver, BC V6T1Z4, Canada

\begin{abstract}
Tree plantations are widely considered a sustainable and economically feasible way to foster reforestation of degraded tropical lands. However, the greatest obstacle to their implementation is the 5-10 years period before initial returns through tree harvesting are realized. This study evaluated the feasibility of generating returns in this period by intercropping hardwood plantations with annual crops. In an agroforestry trial established in eastern Panama, the costs and revenues of intercropping five native and one exotic (Tectona grandis) tree species with three different agricultural treatments-maize-beans, pigeon pea and cassava-were assessed. All tree-crop combinations, except those with cassava, generated positive net cash flows during the first years. Over the modeled rotation period of 25 years, the agrisilvicultural systems showed up to $50 \%$ higher net present values (NPV) than pure forestry (given a $6 \%$ interest rate), while most tree-crop combinations exceeded the NPV of pure agriculture. T. grandis intercropped with pigeon pea showed the best economic performance. The NPVs of the agrisilvicultural systems were less sensitive to changes in costs or revenues than either pure forestry or pure agriculture. Accordingly, the final felling value required for intercropping treatments to meet the desired interest rate of $6 \%$ was up to $90 \%$ lower than that for pure forest plantations. This effect was strongest for native tree species, as their slower growth allowed for longer periods of intercropping. Results suggest that intercropping hardwood plantations can be an effective tool for improving financial feasibility of reforestation while providing increased food security in rural areas.
\end{abstract}




\section{Keywords}

Intercropping, Taungya, Tectona grandis, Terminalia Amazonia, Hieronyma alchorneoides, Cajanus cajan

\section{Introduction}

In the Central American Republic of Panama, $27 \%$ of the total land area has been degraded (ANAM 2011).

Soil has become degraded through the conversion of forests into agricultural land and subsequent unsustainable land use practices-particularly repeated burning and overgrazing of pastures (Love and Spaner 2005). Forests provide important ecosystem services which can only be restored through reforestation (Sands 2005; Reid 2005; Chazdon 2008). As natural regeneration is usually very slow (Günter et al. 2007; Palomeque 2012; Goers et al. 2012), and secondary forests often comprise few economically valuable species (Günter et al. 2008; Akindele and Onyekwelu 2011), the establishment of hardwood plantations is considered a sustainable and economically feasible way to rehabilitate degraded and unproductive land (Cubbage et al. 2010; Knoke et al. 2013). Active reforestation requires a substantial up-front investment in tree seedlings and planting. This is a financial burden that many farmers might not be willing to take on, considering that it is likely to be up to 10 years before they receive the first returns from their investment. Agroforestry might be a way to help overcome this obstacle.

The most widely applied agroforestry practice used to foster reforestation is the "Taungya" practice (Jordan 1992). Taungya is the simultaneous cultivation of annual crops during the initial years of plantation establishment during which no returns from timber sales can be expected. While the Taungya practice has been widely applied in Asia (Jordan 1992), few examples are available from Central America (Current et al. 1995; Schlönvoigt and Beer 2001). The simultaneous planting of short-term crops during the initial phase of forest plantations might have positive effects on young trees and seedlings, such as suppression of competing grasses, reductions in soil transpiration and improvements in microclimate and soil fertility (Watanabe 1992; Vieira et al. 2009). Revenues from crops might also help offset costs for the management of tree seedlings, thus improving the financial feasibility of forest plantations (Witcomb and Dorward 2009; Kalame et al. 2011). A systematic comparison of this agroforestry practice with modern forest plantations from both short and long-term perspectives is, to date, lacking.

This study was designed to estimate the potential of the timber-based intercropping system to increase the financial viability of reforestation of degraded lands in Central America. The research questions addressed were: 
1) Can an agrisilvicultural approach generate net income during the initial years following plantation establishment?

2) Will an agrisilvicultural concept be more profitable than pure forestry when the entire rotation period of 25 years is considered?

3) Can an agrisilvicultural concept compete financially with pure crop cultivation or cattle farming?

4) How sensitive will the different land-use options be to possible price (and yield) changes in the future?

The few studies available on potential tree intercropping systems in Central America have focused mainly on the use of fast-growing tree species which are not native to Central America, such as Eucalyptus deglupta (Schlönvoigt and Beer 2001), Acacia spp.(Kapp and Beer 1995; Gó mez 1995), and Tectona grandis (Current et al. 1995), as they are often favored over native tree species for use in commercial reforestation projects due to their faster growth rates and longer breeding histories (ANAM 2010). Accordingly, $66 \%$ of the reforested area in Panama today has been planted in T. grandis (ANAM 2010). As the ecological benefit of such monocultures is debated (Bremer and Farley 2010; Griscom and Ashton 2011), this study was also designed to assess the economic potential of hardwood species native to Panama, namely Astronium graveolens, Cedrela odorata, Dalbergia retusa, Hieronyma alchorneoides and Terminalia amazonia, for use in timber-based agrisilvicultural systems as compared to the exotic tree species Tectona grandis.

\section{Materials and methods}

\section{The study area}

The study was carried out in the district of Chepo in eastern Panama near the township of Tortí $\left(8^{\circ} 54^{0} 21^{00} \mathrm{~N}, 78^{\circ} 20^{\circ} 01^{00} \mathrm{~W}\right)$. This region is considered to be part of the tropics, with average annual precipitation of $1,910 \mathrm{~mm}$ and an average annual temperature of $26.4^{\circ} \mathrm{C}$ (ETESA 2011). The three month dry season, during which less than $30 \mathrm{~mm}$ of rain falls monthly, occurs from January to March (ETESA 2011). The soils in the site where the trial was established are classified as Vertisols, with a clay content of up to $80 \%$, and are seasonally waterlogged. These unfavorable soil conditions, together with the fact that the site was formerly used as cattle pasture, make it an ideal example, as equivalent sites are often used for reforestation in Panama (Tschakert et al. 2007; Sloan 2008). 


\section{Trial design and management}

The trial was established within the framework of a reforestation project which covers a total area of 74 ha. Three different treatments - agroforestry, pure forestry and pure crop cultivation - were monitored over a total period of 24 months. In the agroforestry treatment, the six tree species mentioned above were planted in combination with three different treatments of either single crops or crop rotation systems that are commonly grown by local farmers (Schuchmann 2011) - (1) Pigeon pea (Cajanus cajan); (2) Maize (Zea mays) followed by beans (Phaseolus vulgaris, local variety "chiriquano") and a second rotation of maize, and (3) Cassava (Manihot esculenta). The trial layout, which is described in detail by Paul (2014), was based on a random plot design with four repetitions per tree-crop combination. For the purpose of this study, we did not consider repetitions, but instead pooled all plots of each treatment together to calculate total crop yields and overall tree growth, respectively and then adjusted them to generate per hectare averages. Costs and revenues from the agroforestry systems were recorded for a total area of 0.5 ha for each treatment. Within this area, the different tree species were planted on replicated mono-species subplots of $200 \mathrm{~m}^{2}$ each. As these small plots were directly adjacent to one another, the costs for weeding did not differ among the different tree species during the observation period. Costs for pure afforestation were monitored in pure stands on a total area of 0.18 ha for each tree species. Pure agricultural production was evaluated on a total area of $900 \mathrm{~m} 2$ per crop or crop rotation system.

\section{Tree management}

The trial was established in August 2009. Before planting, the site was manually cleared of grasses using machetes and then treated with the herbicide Glyphosate ( $N$-(phosphonomethyl)glycine) $\left(4 \mathrm{lha}^{-1}\right)$ - common practices for land preparation used by local farmers. Containerized tree seedlings of $D$. retusa were planted at $2 \times$ $3 \mathrm{~m}$ intervals, while seedlings of all other species were planted at a distance of $3 \times 3$ $\mathrm{m}$, representing commonly practiced tree spacing used by the cooperating reforestation company (ForestFinance Group). Four days after planting, $20 \mathrm{~g}$ of NPK-fertilizer (15-30-8) was applied to each seedling. Any individuals that died during the first 12 months after the initial planting were replaced (Online Resource (OR) 1, Table B). During the first 4 months after plantation establishment, any emerging vegetation was repeatedly cut in a circle of one meter around each tree ('spot-ringed weeding') using machetes. In the agroforestry trial, subsequent weed control was carried out during the course of crop management, while in the pure forest plantation plots, competing vegetation was cut manually and subsequently treated with herbicide (OR 1, Table A) once every 4 months. From year five on, maintenance modeled costs for tree plantations were reduced according to information obtained from ANAM (2011) and local plantation managers (Table A, 
OR1). With the exception of $T$. amazonia all trees required singling and pruning. In order to reduce damage to $C$. odorata trees from the mahogany shoot borer $(H$. grandella), trees of this species were monitored every 3 months, beginning 6 months after planting (see Paul and Weber 2013). Any infested branches detected were cut and burned.

\section{Crop management}

All crops were planted manually, using commonly applied planting techniques (Schuchmann 2011). All crops were planted in the weeks immediately following tree planting. However, as pigeon pea was planned as the second part of a rotation with ginger, which failed to germinate, this agroforestry treatment actually contained no crops until 9 months after tree planting, at which time pigeon pea was sown. Thus, for a more accurate comparison with other crop rotations, we also calculated the option "Pigeon pea starting at year 0", a scenario in which pigeon pea is planted few weeks after tree seedlings. The seeds for all crops with the exception of maize (DK1040) were obtained from local farmers. In both the agroforestry and the pure agricultural treatments, crops were sown in a regular grid between trees, using planting distances of $1 \times 1 \mathrm{~m}$ for pigeon pea and cassava, $0.9 \times 0.3 \mathrm{~m}$ for maize and $0.7 \times 0.3 \mathrm{~m}$ for beans. In the agroforestry treatments a radius of $50 \mathrm{~cm}$ around each tree was left free of crops. Hence, for every 1 ha of available ground, only 0.91 ha were used for crop production. In order to meet the certification standards of the Forest Stewardship Council (FSC), no pesticides were applied in either the agroforestry plots or the pure agricultural plots. The rotation length for pigeon pea was 9 months, and that for cassava, 12 months. In the maize-beans-maize treatment, the first maize was harvested 3 months after tree planting. Beans were then immediately sown, and after 4 months, harvested. Due to the dry season, a fallow period of 3 months followed the bean harvest, after which the seeds for the last maize rotation were sown. While the first maize rotation was fertilized using $180 \mathrm{~kg} \mathrm{ha}^{-1}$ of $15-30-8$ NPK-fertilizer, the second rotation received no fertilizer, due to the previous planting of legumes. Maize was harvested as fresh corn cobs, and beans were harvested as dried seed pods which were subsequently threshed. Pigeon peas were picked and sold as green pods (Table 1). 
Table 1 Revenues from crops in agroforestry (AF) and pure agriculture (CP) in years zero and one, respectively

\begin{tabular}{|c|c|c|c|c|c|c|c|}
\hline \multirow[t]{2}{*}{ Crop (rotation) } & \multirow[t]{2}{*}{ Agricultural product } & \multirow[t]{2}{*}{ Unit } & \multicolumn{2}{|c|}{ Yield/ha } & \multirow{2}{*}{$\begin{array}{l}\text { Price per } \\
\text { unit }(\$)\end{array}$} & \multicolumn{2}{|c|}{ Revenue $\left(\$ \mathrm{ha}^{-1}\right)$} \\
\hline & & & $\mathrm{AF}$ & $\mathrm{CP}$ & & $\mathrm{AF}$ & $\mathrm{CP}$ \\
\hline \multirow[t]{7}{*}{ Maize-beans-maize } & $\begin{array}{l}\text { Maize rotation with fertilizer-high } \\
\text { quality cobs }\end{array}$ & No. of corn cobs ${ }^{a}$ & 19,112 & 21,023 & 0.07 & 1,338 & 1,472 \\
\hline & $\begin{array}{l}\text { Maize rotation with fertilizer-low } \\
\text { quality cobs }\end{array}$ & No. of corn cobs & 4,788 & 5,267 & 0.03 & 144 & 158 \\
\hline & Maize with fertilizer-total & & & & & 1,482 & 1,630 \\
\hline & Beans & Quintal $^{\mathrm{b}}$ (qq) & 6.9 & 7.6 & 55.00 & 380 & 418 \\
\hline & $\begin{array}{l}\text { Maize rotation without fertilizer- } \\
\text { high quality cobs }\end{array}$ & No. of corn cobs & 13,560 & 14,916 & 0.07 & 949 & 1,044 \\
\hline & $\begin{array}{l}\text { Maize rotation without fertilizer-low } \\
\text { quality cobs }\end{array}$ & No. of corn cobs & 3,390 & 3,729 & 0.03 & 102 & 112 \\
\hline & Maize without fertilizer--total & & & & & 1,051 & 1,156 \\
\hline \multirow[t]{3}{*}{ Pigeon pea } & Pigeon Pea—green pods & Quintal (qq) & 24.5 & 27.0 & 0.60 & 1,471 & 1,620 \\
\hline & Pigeon Pea-dried seeds & Quintal (qq) & 5.9 & 6.5 & 55.00 & 326 & 357 \\
\hline & PigeonPea-total & & & & & 1,797 & 1,977 \\
\hline Cassava & Cassava & Quintal (qq) & 78.5 & 86.4 & 10.00 & 785 & 864 \\
\hline Cattle farming & Cattle for meat production & Cow & & 4 & 550 & & 2,200 \\
\hline
\end{tabular}

Please note that yields in the agroforestry systems were predicted to decrease over time, as shown in Table 1

${ }^{\mathrm{a}}$ Corn cobs were sold per sack of 100 fresh corn cobs

b 1 qq equals $100 \mathrm{lb}$ or around $46 \mathrm{~kg}$

\section{Data collection}

All costs and revenues for the three treatments were recorded during the first 24 months (Fig. 1; Table 4).Costs for purchase of land and taxes were omitted from these calculations. Labor costs were calculated based on a wage of US\$ 14 per day - the actual salary paid to workers during the trial, which included social security contributions and health insurance payments.

All costs are provided in US\$ ha ${ }^{-1}$ - shortened to $\$ \mathrm{ha}^{-1}$ from here on. The costs considered in our analysis also include expenses for technical and legal assistance, maintenance of general infrastructure and other similar costs. These costs were based on information from MIDA (2011) and ANAM (2010) and take into account the fact that forestry activities usually require more elaborate planning and monitoring than agricultural activities.

\section{Modeling of future income and costs from crops}

Future crop yields in any agroforestry system depend mainly on tree growth and the canopy traits of the associated tree species. The yields of $\mathrm{C} 4$ plants such as maize have, for instance, been shown to be reduced at the same magnitude as decreases in light transmission due to shading from tree canopy cover, (Friday 
and Fownes 2002, Ding and Su 2010), which is dependent on the trees' crown structure. Data on light transmission in young stands of the investigated species are scarce (Table C OR1). We therefore used crown coverage-defined as the mean crown radius of each tree species at a certain age - as a proxy variable for yield reduction, assuming that crop cultivation would no longer be possible on the area covered by a tree canopy. Using this crown cover approach alone might lead to biased results, as canopy traits are not considered. For instance, $T$. grandis has a very small conical crown but a very fast monopodial growth, leading to a small reduction in the area available for crops but to a relatively high level of shading. In contrast, the flat-topped spreading crown and small leaves of D. retusa lead to a high crown projection area but low levels of shading (Waltenberger 2013, OR1, Table C). Therefore, we built simplified categories for yield reduction which take into account both crown diameters and tree heights, and are based on an empirical data set (Table 2, see OR 1, Table D for details).

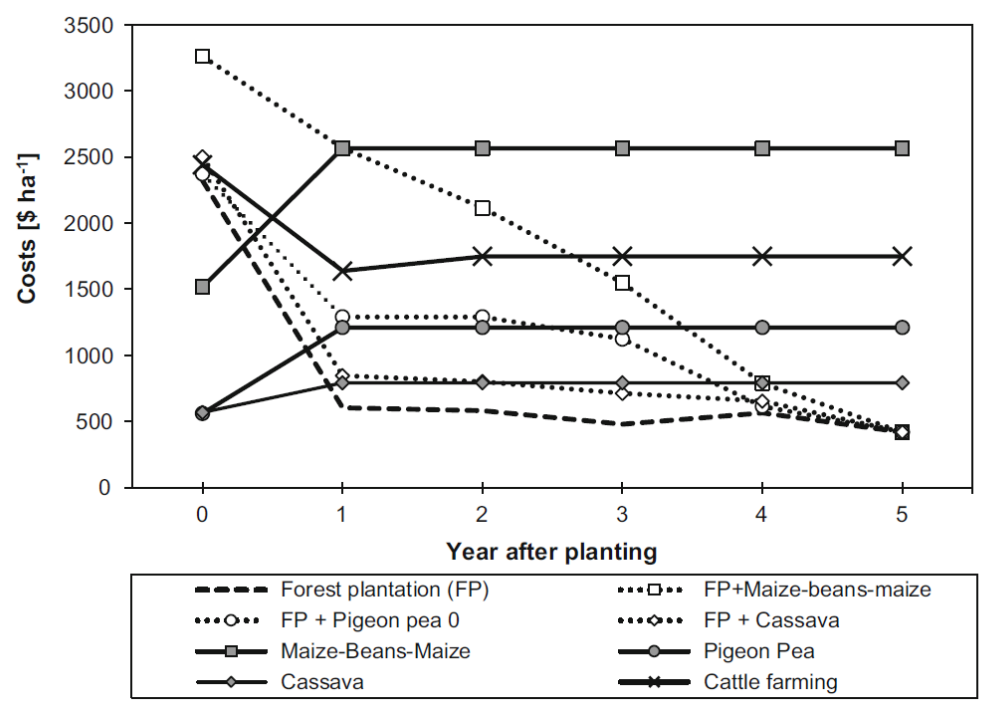

Figure 1: Comparison of costs for pure agriculture (solid lines) with those for agroforestry systems (dotted lines) and pure forest plantations (dashed line) during the initial phase. Data shown for both agroforestry systems and pure forest plantations are based on those assumed for T. amazonia. Pigeon pea 0 refers to pigeon pea cultivation starting in year zero. Please note: data from year three on are based on assumptions presented in the text.

The derived yield reduction scenario for pigeon pea differed slightly from that for the other crops, as the yield data from the first pigeon pea rotation revealed that the yield per shrub increased with decreasing shrub densities, with the highest yields occurring at a density of around $0.2 \mathrm{shrub} / \mathrm{m}^{2}$ (Kreuzer 2013). Therefore, similar yields could be assumed, even if fewer shrubs were to be planted in a more widely spaced grid. 
As shown in Table 2, native tree species allowed for longer crop cultivation, due to their lower growth rates (see also Table 3). As crop production in the agroforestry systems decreased over time with increasing crown cover, costs for weeding, harvesting and transport were adjusted accordingly. Yields in the pure agriculture options were assumed to remain constant over time.

\section{Modeling of future income and costs from trees}

Future management operations in the pure forest plantations, as well as those that could be expected to take place in the agroforestry systems after crops were shaded out, were estimated based on data from the cooperating companies and ANAM (2010) (OR 1, Table A). In order to predict future income from trees, growth rates for each tree species were derived from the literature (Table 3 and see OR 1, Table F). Table 3 demonstrates that rather conservative increments were selected in order to avoid overestimation of tree growth.

Table 2 Yield reduction scenario for pigeon pea $(\mathrm{P})$ and all other crops in the agroforestry system by tree species

\begin{tabular}{|c|c|c|c|c|c|c|c|c|c|c|}
\hline \multirow[t]{2}{*}{ Tree species } & \multicolumn{2}{|c|}{ Year 0} & \multicolumn{2}{|c|}{ Year 1} & \multicolumn{2}{|c|}{ Year 2} & \multicolumn{2}{|c|}{ Year 3} & \multicolumn{2}{|c|}{ Year 4} \\
\hline & $P$ & Others & $P$ & Others & $P$ & Others & $\mathrm{P}$ & Others & $P$ & Others \\
\hline A. graveolens & 1 & 1 & 1 & 1 & 1 & 1 & 1 & 0.75 & 0.75 & 0 \\
\hline C. odorata & 1 & 1 & 1 & 1 & 1 & 1 & 1 & 0.75 & 0.75 & 0 \\
\hline D. retusa & 1 & 1 & 1 & 1 & 1 & 0.75 & 1 & 0.5 & 0.5 & 0 \\
\hline $\begin{array}{l}H . \\
\text { alchorneoides }\end{array}$ & 1 & 1 & 1 & 1 & 1 & 1 & 1 & 0.75 & 0.75 & 0.5 \\
\hline T. grandis & 1 & 1 & 1 & 1 & 1 & 0.5 & 1 & 0 & 0 & 0 \\
\hline T. атаzonia & 1 & 1 & 1 & 1 & 1 & 0.75 & 1 & 0.5 & 0.5 & 0 \\
\hline
\end{tabular}

Table shows factors to be multiplied by the yield in year zero (Table 1). For justification of these assumptions see OR 1, Table C and D

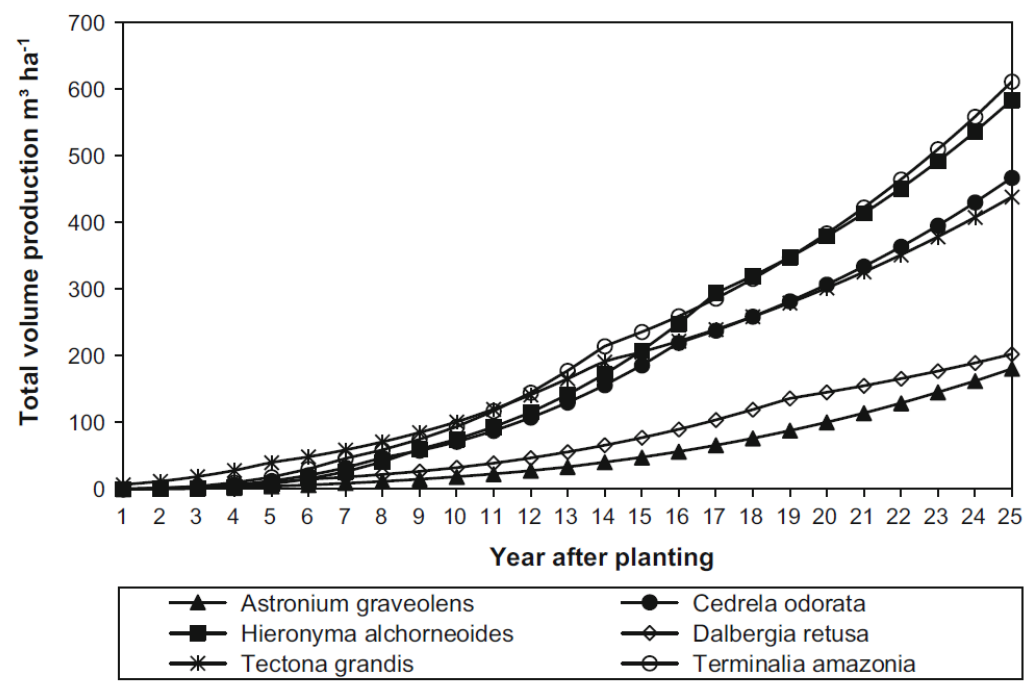

Figure 2: Modeled total volume production [m3/ha] of the tree species investigated 
Figure 2 shows that the total predicted volume production for T. amazonia, H. alchorneoides and C. odorata of up to $600 \mathrm{~m}^{3} \mathrm{ha}^{-1}$ exceeds that which was expected from $T$. grandis after the first 10 years-as also shown by Piotto et al. (2010) and Griess and Knoke (2011). The slow-growing tree species A. graveolens and D. retusa would still only have achieved total increments of 202 and $180 \mathrm{~m}^{3} \mathrm{ha}^{-1}$, respectively by year 25 .

Two thinning operations took place within the modeled 25-year rotation. The first pre-commercial thinning was designed to reduce stem number by $40 \%$ (and 50 $\%$ for D. retusa), as suggested by Evans and Turnbull (2004), and was carried out at the time of crown closure, which was estimated using the data presented in OR 1 (Table C). The second thinning reduced stem number by $50 \%$, and was timed to take place when the basal area had reached $20 \mathrm{~m}^{2}$ ha $^{-1}$, as suggested by Kanninen et al. (2004) and Mayhew and Newton (1998). All yield tables are reported in detail in OR 1, Table F. In accordance with Griess and Knoke (2011) and Piotto et al. (2010), $64 \%$ of harvested wood volume was assumed to be sold as stem wood. Wood prices were derived from the National Forest Office of Costa Rica (ONF 2012), as no detailed information on wood prices was available for Panama (see information given in OR 1, Table E). Harvesting costs were calculated based on ANAM (2010) (OR 1, Table F). Modeling of cattle farming

Cattle farming is the main generator of household income in the region (Tschakert et al. 2007). Costs and revenues for this land-use system were derived from Schuchmann (2011), and from key informants from state institutions such as the Ministry of Agricultural Development of Panama (MIDA) and the Institute for Agricultural Research of Panama (IDIAP). To avoid underestimation of the profitability of cattle farming, we used relatively advanced techniques of cattle farming in our simulation-including the use of improved pasture grasses and a rotational pasture system - which resulted in a relatively high stocking level of four cows per ha (Hänsela et al. 2009; Murgueitio et al. 2011). According to INEC (2011), $82 \%$ of the farmers in the township of Tortí actually sow pasture grasses, while 18 $\%$ have pastures which are naturally regenerated. Cows in the simulation were purchased and pastured to fatten them up for meat production. Meat prices were obtained from the livestock market in Chepo. 
Table 3 Literature review on growth data of tree species investigated on comparable sites in the lowland humid tropical climate of Central America

\begin{tabular}{|c|c|c|c|c|c|c|c|}
\hline Source & Age & Location & Initial S/ha & $\begin{array}{l}\mathrm{dbh} \\
(\mathrm{cm})\end{array}$ & $\begin{array}{l}\mathrm{h} \\
(\mathrm{m})\end{array}$ & $\begin{array}{l}\text { MAI dbh } \\
(\mathrm{cm} / \mathrm{yr})\end{array}$ & $\begin{array}{l}\text { MAI h } \\
(\mathrm{m} / \mathrm{yr})\end{array}$ \\
\hline \multicolumn{8}{|l|}{ A. graveolens } \\
\hline on-trial data & 2 & Tortí, Panama & 1,111 & 2.0 & 2.1 & 1.0 & 1.0 \\
\hline ForestFinance (2012) & 4 & Darien, Panama & 1,111 & 4.1 & 3.2 & 1.0 & 0.8 \\
\hline Piotto et al. (2004) & 5.5 & $\begin{array}{l}\text { Peninsula of Nicoya, } \\
\text { Costa Rica }\end{array}$ & 1,111 & 6.48 & 4.71 & 1.2 & 0.9 \\
\hline Cordero and Boshier (2003) & 8 & Honduras & 2,500 & - & - & 1.0 & 0.5 \\
\hline Cordero and Boshier $(2003)^{a}$ & 13 & Costa Rica & 2,500 & - & - & $0.8-1$ & $0.6-0.8$ \\
\hline Cordero and Boshier (2003) & 31 & Honduras & 278 & 17.7 & 22.1 & 0.6 & 0.7 \\
\hline \multicolumn{8}{|l|}{ C. odorata } \\
\hline on-trial data & 2 & Tortí, Panama & 1,111 & 2.9 & 2.4 & 1.5 & 1.2 \\
\hline ForestFinance (2012) & 4 & Darien, Panama & 1,111 & 4.8 & 4.6 & 1.2 & 1.2 \\
\hline Cordero and Boshier (2003) ${ }^{a}$ & $<5$ & $\begin{array}{l}\text { Nicaragua and } \\
\text { Honduras }\end{array}$ & uk & - & - & $1.3-1.6$ & $1.3-1.6$ \\
\hline Piotto et al. (2004) & 5.7 & $\begin{array}{l}\text { Peninsula of Nicoya, } \\
\text { Costa Rica }\end{array}$ & 2,500 & 3.0 & 1.7 & 0.5 & 0.3 \\
\hline Condit and Sautu (2001) & 8 & Costa Rica & & $15-22$ & $12-15$ & 2.3 & 1.7 \\
\hline Whitmore (1978) & 8 & Puerto Rico & 1,736 & 4.4 & 4.5 & 0.5 & 0.5 \\
\hline Whitmore (1978) & 8 & Virgin Islands, USA & 1,736 & 5.9 & 4.5 & 0.7 & 0.6 \\
\hline Wadsworth (1960) & 8 & Mexico & 1,111 & 11 & 6 & 1.4 & 0.7 \\
\hline Wadsworth (1960) & 12 & Mexico & 10,000 & 8 & 6 & 0.7 & 0.7 \\
\hline Wadsworth (1960) & 12 & Panama & 2,222 & 24 & 21 & 2.0 & 1.7 \\
\hline Wadsworth (1960) & 13 & Honduras & 2,222 & 28 & 15 & 2.1 & 1.1 \\
\hline Wadsworth (1960) & $18-20$ & Ecuador & 1,111 & 50 & 25 & 2.5 & 1.2 \\
\hline Lamb (1968) & 25 & Sapoba, Nigeria & 1,550 & 40 & 32 & 1.6 & 1.3 \\
\hline Lamb $(1968)^{\mathbf{a}}$ & 32 & Sapoba, Nigeria & 1,550 & 45 & 37 & 1.4 & 1.2 \\
\hline \multicolumn{8}{|l|}{ D. retusa } \\
\hline on-trial data & 2 & Tortí, Panama & 1,111 & 2.9 & 2.4 & 1.5 & 1.2 \\
\hline ForestFinance (2012) & 4 & Darien, Panama & 1,111 & 4.8 & 4.6 & 1.2 & 1.2 \\
\hline ForestFinance (2012) & 7 & Chiriqui & 1,111 & 7.2 & 9.11 & 1.0 & 1.3 \\
\hline Piotto et al. (2004) & 5.7 & $\begin{array}{l}\text { Peninsula of Nicoya, } \\
\text { Costa Rica }\end{array}$ & 1,111 & 6.99 & 5.4 & 1.2 & 0.9 \\
\hline Hazlett (1980) & 31 & Honduras & uk & - & - & 0.8 & - \\
\hline Cordero and Boshier (2003) & 11 & Costa rica & 2,500 & - & - & 1.0 & 0.6 \\
\hline \multicolumn{8}{|l|}{ H. alchorneoides } \\
\hline on-trial data & 2 & Tortí, Panama & 1,111 & 1.5 & 1.7 & 0.8 & 0.9 \\
\hline ForestFinance (2012) & 4 & Darien, Panama & 1,111 & 4.2 & 3.7 & 1.1 & 0.9 \\
\hline ForestFinance (2012) & 15 & Las Lajas & 1,111 & 22.5 & 22 & 1.5 & 1.5 \\
\hline Montagnini et al. (2003) & 6 & $\begin{array}{l}\text { Northeast of Costa } \\
\text { Rica }^{\text {b,c }}\end{array}$ & 2,500 & 10.3 & 11.9 & 1.8 & 2.0 \\
\hline Griess and Knoke (2011) & 10 & Las Lajas & 400 & 13.4 & 15.3 & 1.3 & 1.5 \\
\hline Griess and Knoke (2011) & 25 & Las Lajas projected & 400 & 34 & 40.3 & 1.4 & 1.6 \\
\hline Piotto et al. (2010) & 16.5 & $\begin{array}{l}\text { Northeast of Costa } \\
\text { Rica }^{\text {b }}\end{array}$ & 2,500 & 18.2 & 23.2 & 1.1 & 1.4 \\
\hline Piotto et al. (2003) & $8-13^{\mathrm{d}}$ & $\begin{array}{l}\text { Northeast of Costa } \\
\text { Rica }\end{array}$ & $1,111-25,00^{\mathrm{d}}$ & - & - & 1.9 & 1.7 \\
\hline
\end{tabular}




\begin{tabular}{|c|c|c|c|c|c|c|c|}
\hline Redondo-Brenes and Montagnini (2006) ${ }^{\mathrm{a}}$ & 13 & $\begin{array}{l}\text { Northeast of Costa } \\
\text { Rica }^{\text {b }}\end{array}$ & 2,500 & 15.5 & 21 & 1.4 & 1.7 \\
\hline Cordero and Boshier (2003) & $>9$ & Costa Rica & 1,111 & - & - & 1.7 & 1.8 \\
\hline Cordero and Boshier (2003) & $<6$ & Costa Rica & 1,111 & - & - & $2.2-2.5$ & $2.3-2.5$ \\
\hline \multicolumn{8}{|l|}{ T. amazonia } \\
\hline on-trial data & 2 & Tortí, Panama & 1,111 & 3.3 & 3.0 & 1.6 & 1.5 \\
\hline ForestFinance (2012) & 3 & Panama & 1,111 & 3.0 & 3.0 & 1.0 & 1.0 \\
\hline ForestFinance (2012) & 4 & Darien & 1,111 & 3.2 & 6.3 & 0.8 & 1.6 \\
\hline ForestFinance (2012) & 5 & Darien & 1,111 & 6.0 & 6.3 & 1.2 & 1.3 \\
\hline ForestFinance (2012) & 15 & Las Lajas & 1,111 & 28.0 & 27.4 & 1.9 & 1.8 \\
\hline Griess and Knoke (2011) & 10 & Las Lajas & 1,111 & 18.8 & 20.0 & 1.9 & 2.0 \\
\hline Griess and Knoke (2011) & 25 & Las Lajas projected & 1,111 & 43.8 & 43.4 & 1.8 & 1.7 \\
\hline Haggar et al. (2003) & 6 & $\begin{array}{l}\text { Northeast of Costa } \\
\text { Rica }^{\mathrm{b}}\end{array}$ & 1,111 & 15.4 & 13.9 & 2.5 & 2.3 \\
\hline Montagnini et al. (2003) & 7 & $\begin{array}{l}\text { Northeast of Costa } \\
\text { Rica }^{\text {b,c }}\end{array}$ & 2,500 & 10.3 & 11.9 & 1.8 & 2.0 \\
\hline Piotto et al. (2003) & $8-13^{\mathrm{d}}$ & $\begin{array}{l}\text { Northeast of Costa } \\
\text { Rica }\end{array}$ & $1,111-25,00^{\mathrm{d}}$ & - & - & 2.4 & 2.0 \\
\hline Redondo-Brenes and Montagnini (2006) & 13 & $\begin{array}{l}\text { Northeast of Costa } \\
\text { Rica }^{\text {b }}\end{array}$ & 2,500 & 22.3 & 21.0 & 1.7 & 1.6 \\
\hline Piotto et al. (2010) & 16.5 & $\begin{array}{l}\text { Northeast of Costa } \\
\text { Rica }^{\text {b }}\end{array}$ & 2,500 & 24.8 & 24.9 & 1.5 & 1.5 \\
\hline Montero and Kanninen (2005) & 30 & $\begin{array}{l}\text { Costa Rica, superior } \\
\text { sites }\end{array}$ & $625-2,500$ & - & - & 2.4 & 2.4 \\
\hline Montero and Kanninen $(2005)^{\mathbf{a}}$ & 30 & $\begin{array}{l}\text { Costa Rica, medium } \\
\text { sites }\end{array}$ & $625-2,500$ & - & - & 1.6 & 1.3 \\
\hline Montero and Kanninen (2005) & 30 & Costa Rica, bad sites & $625-2,500$ & - & - & 1.0 & 0.7 \\
\hline \multicolumn{8}{|l|}{ T. grandis } \\
\hline on-trial data & 2 & Tortí, Panama & 1,111 & 6.5 & 6.4 & 3.2 & 3.2 \\
\hline ForestFinance (2012) & 3 & Panama & 1,111 & 7.6 & 7.8 & 2.5 & 2.6 \\
\hline ForestFinance (2012) & 4 & Darien & 1,111 & 10.5 & 10.1 & 2.6 & 2.5 \\
\hline ForestFinance (2012) & 15 & Las Lajas & 1,111 & 19.6 & 17.9 & 1.3 & 1.2 \\
\hline Griess and Knoke (2011) & 10 & Las Lajas & 714 & 18.3 & 17.1 & 1.8 & 1.7 \\
\hline Griess and Knoke (2011) & 25 & Las Lajas projected & 714 & 37 & 25.4 & 1.5 & 1.0 \\
\hline Redondo-Brenes and Montagnini (2006) & 13 & $\begin{array}{l}\text { Northeast of Costa } \\
\text { Rica }^{\mathrm{b}}\end{array}$ & & & & & 0.0 \\
\hline Pérez and Kanninen (2005) & 30 & $\begin{array}{l}\text { Costa Rica, medium } \\
\text { site quality max. } \\
\text { vol. }\end{array}$ & 1,111 & 36.6 & 32.4 & 1.2 & 1.1 \\
\hline Pérez and Kanninen $(2005)^{\mathrm{a}}$ & 30 & $\begin{array}{l}\text { Costa Rica, medium } \\
\text { site quality max. } \\
\text { dbh }\end{array}$ & 1,111 & 38.9 & 25.9 & 1.3 & 0.9 \\
\hline Pérez and Kanninen (2005) & 30 & $\begin{array}{l}\text { Costa Rica, high site } \\
\text { quality max. vol. }\end{array}$ & 1,111 & 45.3 & 32.4 & 1.5 & 1.1 \\
\hline Pérez and Kanninen (2005) & 30 & $\begin{array}{l}\text { Costa Rica, high site } \\
\text { quality max. dbh }\end{array}$ & 1,111 & 47.8 & 32.4 & 1.6 & 1.1 \\
\hline Piotto et al. (2004) & 5.7 & $\begin{array}{l}\text { Peninsula of Nicoya, } \\
\text { Costa Rica }\end{array}$ & & 14.0 & 10.7 & 2.5 & 1.9 \\
\hline Piotto et al. (2003) & $8-13^{\mathrm{d}}$ & $\begin{array}{l}\text { Northeast of Costa } \\
\text { Rica }\end{array}$ & $1,111-25,00^{\mathrm{d}}$ & & & 2.4 & 1.9 \\
\hline FAO (2002) & $25-30$ & Panama & - & - & - & $1.1-2.0$ & $1.1-2.0$ \\
\hline $\begin{array}{l}\text { Initial S/ha stem number at time of planting } \\
\text { MAI height mean annual increment in heigl } \\
\text { a Selected growth rates for this study } \\
\text { b La Selva Research Station } \\
{ }^{\mathrm{c}} \text { Data of unthinned stands are cited } \\
{ }^{\mathrm{d}} \text { On-farm research on plantations with diff }\end{array}$ & $\begin{array}{l}\text { per ha, } d \\
\text { t, } u k \text { unk }\end{array}$ & $\begin{array}{l}\text { bh diameter at breast he } \\
\text { nown }\end{array}$ & ight, $h$ height, $M$ & $I A I d b h$ & hean ar & al increm & t in dbh, \\
\hline
\end{tabular}




\section{Ranking method and sensitivity analysis}

The NCF- the difference between cash inflows (or revenues) and cash outflows (or expenses) - was calculated for each year. This measure does not include the "time value of money", which refers to the fact that most individuals prefer to consume now rather than later (Buongiorno and Gilless 2003). Because forestry and agroforestry practices involve investments over a long time horizon, we calculated the NPV to allow for comparison among the economic performances of different land use options over the entire rotation period.

$$
\mathrm{NPV}=\sum_{t}^{T} \mathrm{NCF}_{t} \times(1+i)^{-t}
$$

where $\mathrm{NCF}_{\mathrm{t}}$ is the Net Cash Flow in year $t$ after stand establishment ${ }^{1}, T$ is the period of consideration (in this case, the rotation length), and $i$ is the decimal discount rate. An interest rate of $6 \%$ was selected, as it is generally assumed for investments in agriculture in Panama (MIDA 2011). A moderate interest rate of 5-6\% has also been recommended and applied in similar studies in Latin America, (see for example, Pearce et al. 2003; Knoke et al. 2009; Castro et al. 2012). The discount rate at which the NPV is equal to zero is known as the internal rate of return (IRR). Investments in forestry and agriculture have various underlying uncertainties: Cash in and outflows are subject to changes due to the volatility of agricultural and timber markets, natural hazards and rising cost for inputs and labor, among other parameters. A sensitivity analysis was carried out to evaluate the financial robustness of land-use systems towards such changes in these key parameters, as proposed by Current et al. (1995) and Martin and van Noordwijk (2011). For this purpose, the impact of a $50 \%$ change in costs and revenues on the NPV was investigated.

\section{Results}

\section{Net cash flow}

In the year of planting, the high establishment costs for timber plantations could not be compensated for by planting crops between trees. Planting maize and beans succeeded in reducing the financial burden of stand establishment due to their shorter rotation periods, but cassava and pigeon pea did not (Fig. 3). Intercropping forest plantations with maize-beans-maize and pigeon pea resulted in a positive NCF in years one and two for T. grandis and from year one through year four for the native tree species (OR 1, Table G). Trees planted in association with cassava was the only treatment that did not generate positive NCFs. This can be

\footnotetext{
${ }^{1}$ The year of plantation establishment is defined as year zero and is not discounted.
} 
explained by the high weeding costs and low yields in this treatment. By selling cassava tubers, management costs for trees of more than $\$ 500 \mathrm{ha}^{-1}$ could still be offset as compared to pure forest plantations. This finding demonstrates the positive effect of intercropping even under low crop yields. Yet, Fig. 3 reveals that agroforestry systems could not compete with pure agriculture in terms of either the magnitude or the stability of NCFs in the first years. However, both forestry and agroforestry provided high future cash inflows after 25 years, ranging between $\$ 78,761 \mathrm{ha}^{-1}$ (D. retusa) and $\$ 15,583 \mathrm{ha}^{-1}(T$. grandis $)$.

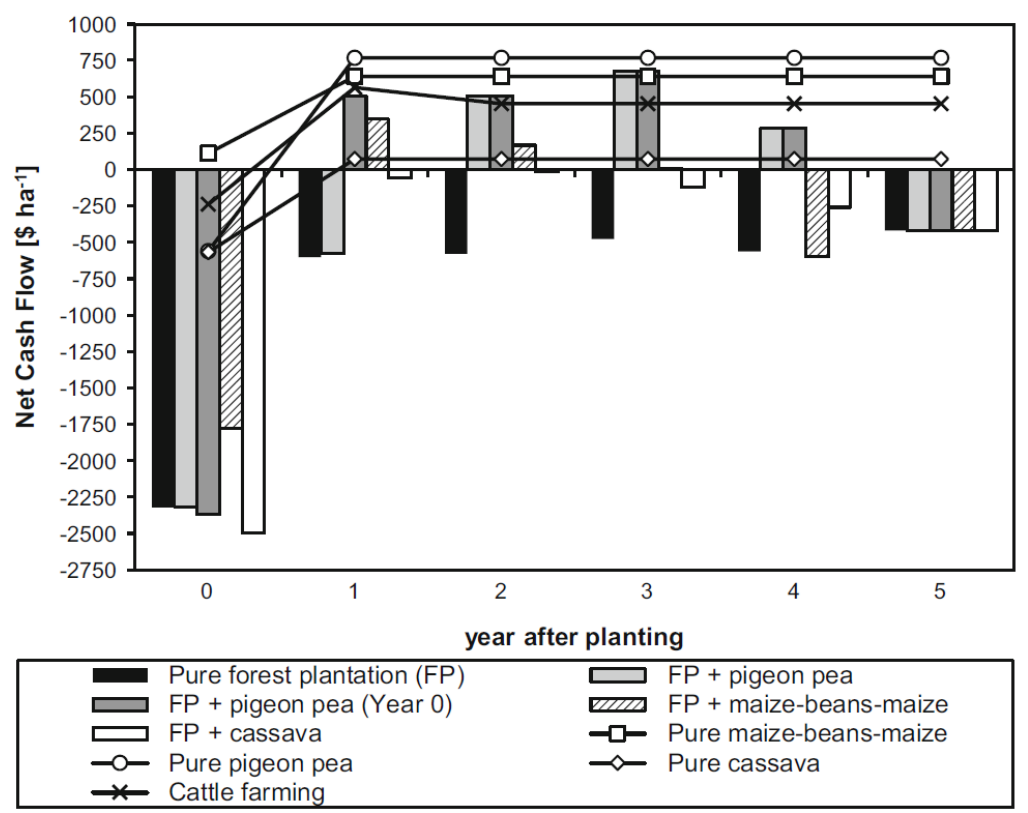

Figure 3: Net cash flow of different land-use options during the first 6 years. Agroforestry and forestry figures are shown for T. amazonia. See OR 1, Table G for Net Cash Flows of all tree-crop combinations over time

\section{Net present value}

The highest NPV over the period of 25 years of all the land-use options investigated was calculated for $T$. grandis plantations intercropped with pigeon pea from year zero on $\left(\$ 17,674 \mathrm{ha}^{-1}\right)$. For all 6 tree species, the NPV was higher when trees were combined with crops than for pure forest plantations (Fig. 4). This was true even for the agroforestry system with cassava, which still improved the NPV by up to $26 \%$, despite the crop's low yields. Intercropping trees with maize-beans-maize and pigeon pea resulted in an up to $50 \%$ higher NPV than that from pure forest stands. Agroforestry was particularly superior to pure forestry for the tree species $C$. odorata, due to the reduction in costs for pest management in the agroforestry systems, as shown by Paul and Weber (2013). 
Figure 4 reveals that all land-use options involving the tree species $T$. grandis and $H$. alchorneoides were more profitable than any of the agricultural options. Planting $T$. amazonia and $C$. odorata was only more cost effective than pure agriculture when planted in association with crops, while $D$. retusa and $A$. graveolens were not able to compete with other land uses economically. It is notable that with the exception of these slow-growing tree species, all tree-crop combinations as well as pure forestry were financially more viable than the most common land-use system in the trial region-cattle farming. In order to show the range of interest rates under which the investment in trees and/or agriculture would still be profitable, we provide the IRRs of all tree-crop combinations in Table 4. This reveals that the agrisilvicultural systems provide IRRs of up to $16 \%$ (excluding the costs for the purchase of land). Neither forestry nor agroforestry could compete, however, with pure agriculture, whose high yearly net income resulted in IRRs of more than $20 \%$. This demonstrates that agroforestry is competitive with other land-use options at moderate interest rates, but not under the high rates of return potentially required by subsistence farmers.

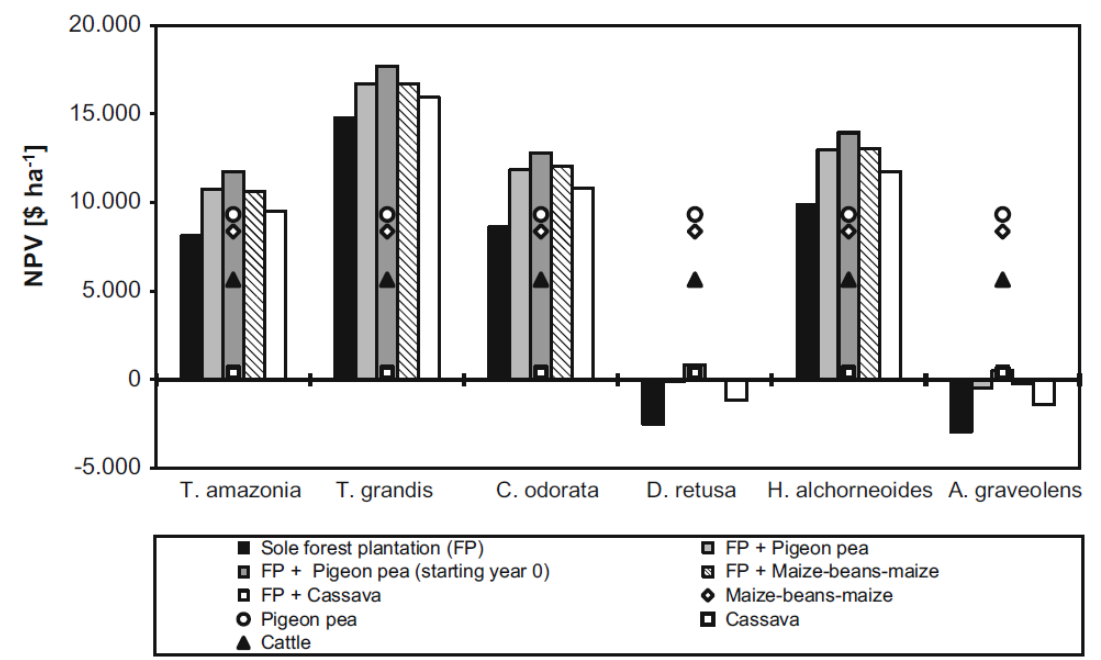

Figure 4: Net present value (NPV) of pure forest stands (black bars) and agroforestry systems (other bars) by tree species compared to pure cropping systems (white symbols) and cattle farming (black triangle) at an interest rate of $6 \%$ and assuming a 25 -year rotation period.

\section{Effect of varying cash in- and outflows}

Figure 5 displays that, despite the range of pessimistic scenarios tested, the NPV of nearly all tree-crop combinations remained positive, with the exception of those with A. graveolens and D. retusa. To increase readability, Fig. 5 only presents the pessimistic scenario for each parameter. However, the relative percentage change in the NPV was the same for the optimistic scenario. These results show that rising costs for forest plantation management can effectively be buffered by 
adding an agricultural component during the period of stand establishment. For instance, if costs were to increase by $50 \%$, the NPV of T. amazonia would decrease by $49 \%$ in the pure forest plantation but only by $11 \%$ when combined with pigeon pea, by $12 \%$ when combined with cassava and by $31 \%$ when planted in combination with maizebeans-maize. Accordingly, the slow-growing species, D. retusa and A. graveolens, would require a cost reduction of 29 and $40 \%$, respectively in order to achieve an IRR of $6 \%$ when grown in pure forest plantation, but only by 1 and $3 \%$, respectively when intercropped with maizebeans-maize. Figure 5 also shows that even under a decrease in revenues from crops of $50 \%$ due to declining yields and/or prices, the agrisilvicultural practice was still more economically advantageous than pure reforestation, with the exception of the labor-intensive maize-beans-maize intercropping system.
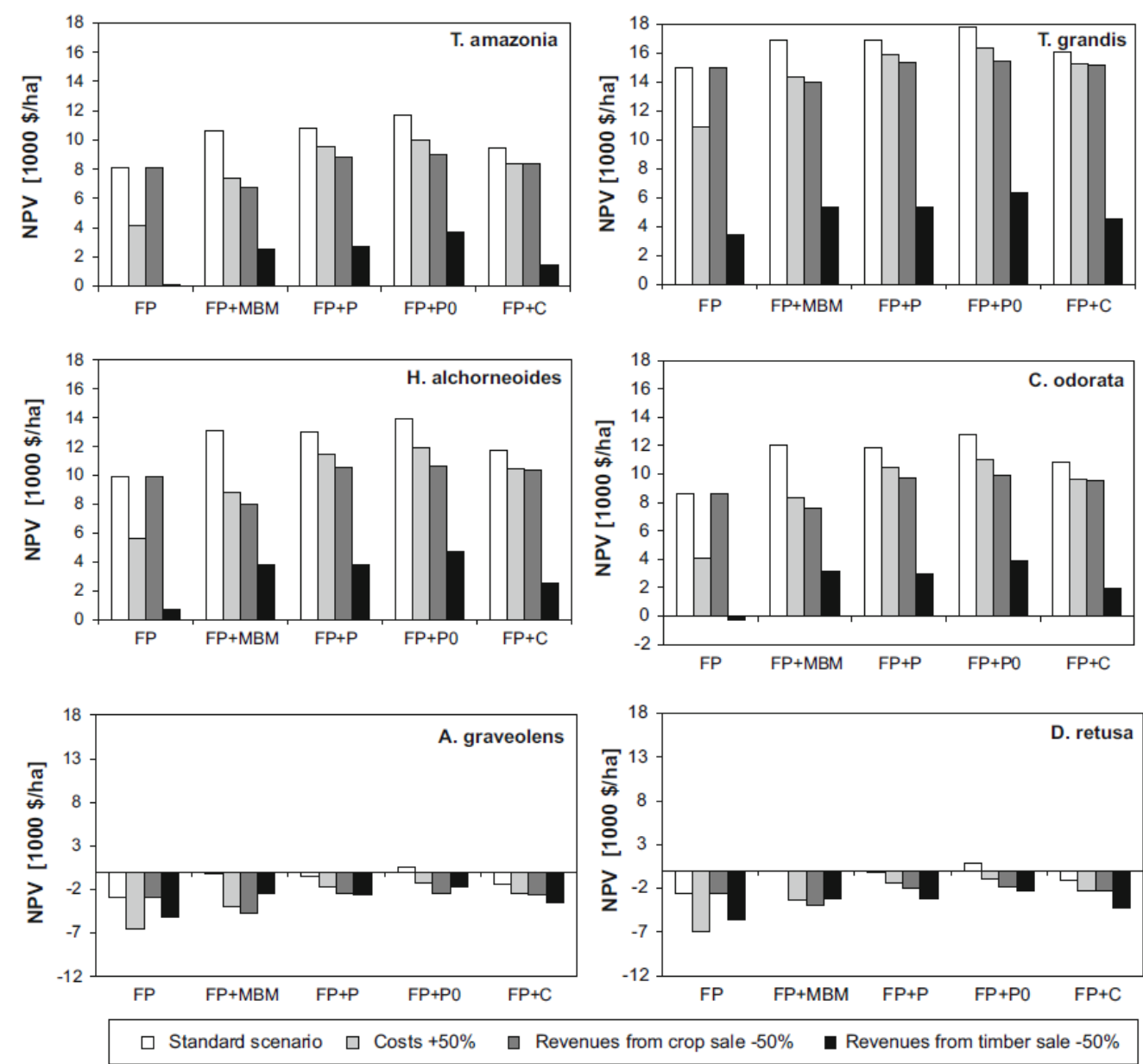

Figure 5: Net present value (NPV) of different tree-crop combinations at an interest rate of $6 \%$ under changing input variables and a rotation length of 25 years $(\mathrm{FP}=$ Forest plantation, $\mathrm{FP}+\mathrm{MBM}$ $=$ Trees intercropped with maize-beans-maize, $\mathrm{FP}+\mathrm{P}=$ Trees intercropped with pigeon pea, $\mathrm{FP}+$ $\mathrm{P} 0=$ Trees intercropped with pigeon pea planted in year $0, \mathrm{FP}+\mathrm{C}=$ Trees intercropped with 
cassava).

The profitability of forest plantations strongly depends on the revenues from timber sales. This effect can be buffered by intercropping, as demonstrated in Fig. 5: In pure forest plantations, a $50 \%$ decline in timber revenues led to a 100 $\%$ decline in the NPV compared to an only 65 to $85 \%$ decline in the agroforestry systems. Despite the risk-reducing effect of the agroforestry system, these numbers clearly display how future yields and wood prices remain the crucial parameters for the profitability of an investment in trees. Predicting these parameters is, particularly difficult, however, not only due to uncertainties in market developments but also because of the lack of knowledge about tree growth performance, appropriate management practices and the probability of calamities caused by fire, wind or insects. By setting the NPV equal to zero and re-arranging Eq. 1, the minimum final felling value (FFV, defined as the harvestable stem volume multiplied by the wood price) required under different interest rates can be calculated. The values given in Fig. 6 can be compared to the FFV predicted in this study (given in Table F, OR1, see black line). Through this approach, the potential decline in the FFV under which the investment would still be beneficial can be estimated. Figure 6 reveals that under a moderate interest rate of $6 \%$, the calculated FFV for T. amazonia $(\$ 59,286 /$ ha see Table F OR1), could still decrease by $60 \%$ in pure forest plantations, and even by up to $87 \%$ in the agroforestry systems, before the investment ceased to be profitable. The difference between pure forestry and agroforestry increased with increasing IRRs, as the advantage of early cash inflows from crops increases in importance with the time value of money. When all of the pure agriculture options were modeled under a $50 \%$ increase in costs, only pure pigeon pea cultivation yielded a positive NPV at a $6 \%$ interest rate. None of the pure agricultural options were profitable under the assumption of a $50 \%$ decrease in revenues. The relative change in NPV would exceed $85 \%$ under a $50 \%$ change in costs, and $135 \%$ under a $50 \%$ reduction in revenues. This high sensitivity of agriculture to varying costs and revenues was caused by the high annual cash-outflows during the modeled period of 25 years. This finding, together with the information presented in Fig. 6, demonstrate the importance of product diversification. 

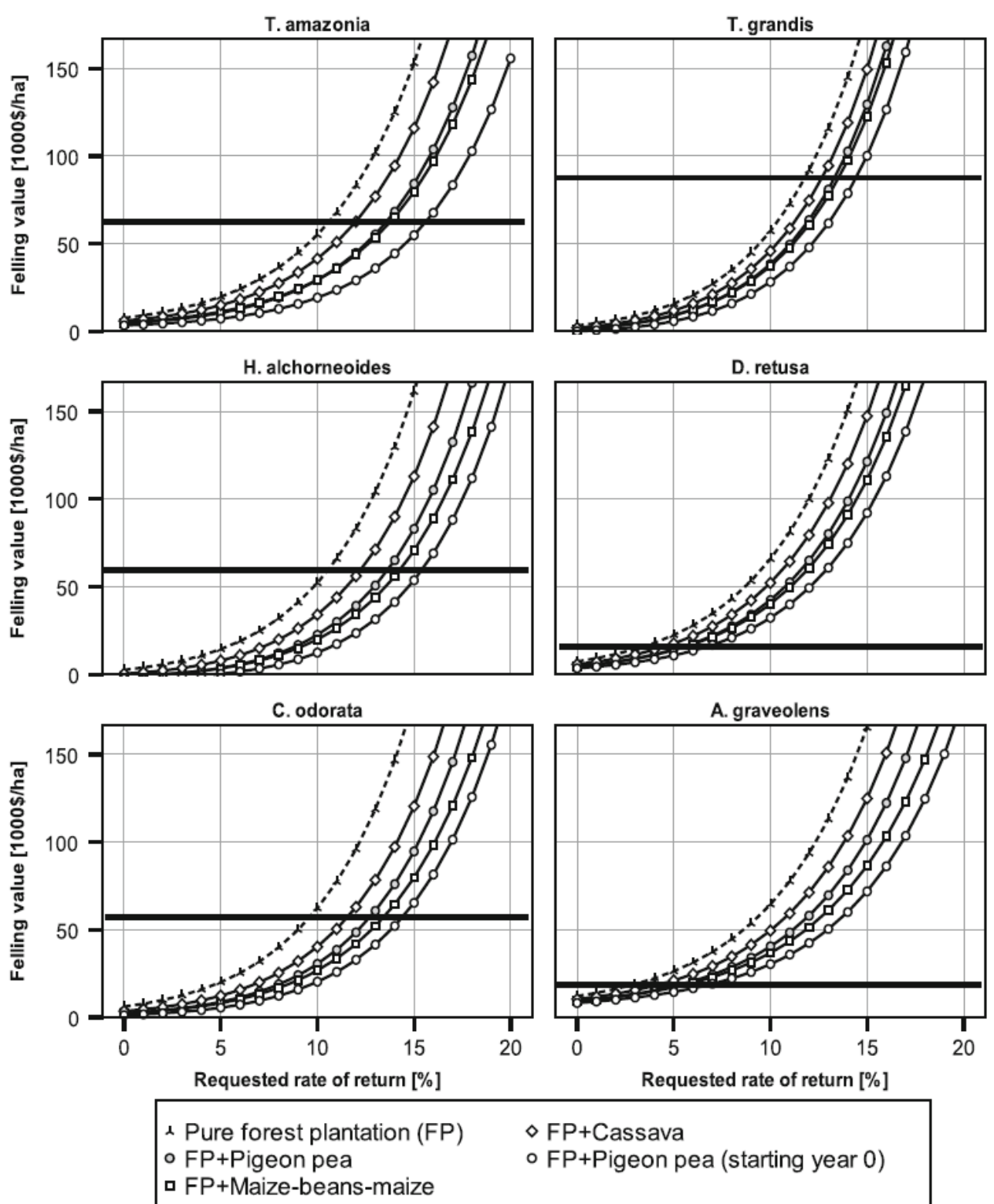

- FP+Pigeon pea

Figure 6: Felling value at which the NPV was equal to zero by interest rate for pure forest plantation (dashed lines) and different tree-crop combinations (solid lines) at a rotation length of 25 years. Straight solid lines represent the actual felling values calculated in this studies (see OR 1, Table F). Y-Axis was cut at 150,000 \$/ha, as a higher final felling value was considered unrealistic 


\section{Discussion}

Financial competitiveness of agrisilvicultural systems versus pure forestry or agriculture

In accordance with the findings of Haggar et al. (2003), intercropping tree seedlings did not fully offset the up-front investment costs of reforestation. However, the rather high costs recorded and estimated in this study apply for commercial forest plantations with the aim of producing high-quality timber. Establishment costs of $\$ 524 \mathrm{ha}^{-1}$, as reported by Coomes et al. (2008) for the same region, are realistic for small-scale reforestation when low day wages and subsidies for tree seedlings (which are usually not available in commercial reforestation projects) are assumed.

However, from years one to four, the agrisilvicultural system gained positive $\mathrm{NCFs}$, leading to clear financial superiority of the agroforestry system compared to pure forest plantations when considering the whole rotation period - a finding that supports the earlier work of Chamshama et al. (1992), Gómez (1995) and Martin and van Noordwijk (2011) in other tropical countries. The advantage of intercropping might even be underestimated in this study, as potential silvicultural advantages leading to improved growth rates and wood quality (Schlönvoigt and Beer 2001; Ceccon 2008; Paul and Weber 2013) were not considered.

Most tree-crop combinations exceeded the NPVs of pure agriculture. However, in terms of magnitude and equal distribution of net income over time, the treerelated land-use options were still not competitive with pure agriculture. It is, however, important to note that the felling operations generated a considerable amount of cash which would then be available for other activities or investments that would otherwise not be feasible for farmers (Franzel 2005). Having a secured "forced" method of saving is an important benefit of planting trees and can support sustainable development in rural areas (Knoke et al. 2012). Other financial incentives, such as potential payments for ecosystem services, were not considered, as they are not yet paid in Panama, even though they could potentially be designed to favor investments in agroforestry and forest plantations in the future (Jose 2009; Maraseni et al. 2012). Revenues from pure cropping systems might have been overestimated, as we assumed that yields would stay constant over time, which is highly questionable (Tilman et al. 2002).

Generalization of the tree and crop yields found in this study is restricted due to the small trial area, and requires further replication. However, we consider this trial to be a representative case study, as it shares a range of conditions commonly found in reforestation projects throughout the world: Tree plantations are usually established on marginal sites which have been abandoned or fallowed by farmers due to less than optimal soil conditions or steep slopes. These characteristics often hinder the use of heavy machinery, and the application of pesticides might be restricted if the forest plantation is to be certified by FSC. The selected research area 
in eastern Panama (districts of Panama and Darien) contains $42 \%$ of the reforested area of Panama (30,795 ha) (ANAM 2010). In these districts, only 0.4 $\%$ of the land is arable, and $12.6 \%$ is arable only given severe or very severe limitations for crop selection and cultivation (ANAM 2011). This is due to the steep slopes on the southern and northern coasts and the high clay content in the lower elevations in the more central parts of the country - as is the case on the trial site (IDIAP 2006, ANAM 2011). Future reforestation projects in eastern Panama are likely to be established on abandoned pastures, which already cover an area of 82,423 ha (12\%) (INEC 2011) and are characterized by conditions similar to those at the trial site. The sensitivity analysis has proven that the economic advantage of tree intercropping is robust against changes in input parameters such as crop and tree yield, strongly suggesting that the results are applicable to other tropical regions as well.

This study also highlights the importance of product diversification in tree plantations to reduce the dependency on uncertain wood prices, even if intercropping is only carried out during the first years.

\section{Choice of tree-crop combinations}

T. grandis is often favored for use in pure forest plantations, due to its ability to quickly shade out grasses and the resulting lower initial demand for labor (Craven et al. 2009). We were able to demonstrate that with the agrisilvicultural approach, the disadvantage of slower canopy closure when using native species can be turned into an advantage: The longer time periods available for generating income from cropping and the additional provision of agricultural goods provide strong arguments for selecting native tree species. Through product diversification, the risk of uncertain future wood prices - particularly with regard to native species - can be buffered, making reforestation with native species a competitive alternative to pure $T$. grandis plantations. Revenues for the native tree species might also have been underestimated here due to the use of rather conservative growth rates and wood prices. D. retusa and C. odorata, for instance, are listed on the IUCN list (IUCN 2012) while the demand for these high-value timber species is high. Exotic tree species that are planted throughout the tropics might, in contrast, encounter a future price decline: Current (1995) discusses that prices for Teak logs in Costa Rica locally declined, when regional markets became flooded with roundwood from even-aged T. grandis plantations.

Paul (2014) demonstrated that the optimal rotation length of $T$. amazonia, $T$. grandis and $C$. odorata was 25 years when interest rates of less than $15 \%$ were applied. This rotation length is generally applied to all species by local reforestation companies. Under the present assumptions, extending the rotation length of the other slow-growing tree species could improve economic performance. Longer rotation periods would not affect the relative superiority of 
agroforestry. In fact, early income from agroforestry could reduce the financially optimal rotation period, particularly for slow-growing tree species (Swallow et al. 1990).

The key advantage of intercropped tree plantations from an economic perspective lies in the reduction of weeding efforts which constitute the highest costs in tropical reforestation during the first years (Evans and Turnbull 2004; Griscom and Ashton 2011). Offsetting these initial costs by selling agricultural products can be critical for the economic profitability of the entire system. This is true because the outgoing payments have a higher weight compared to later outgoing payments when the time value of money is taken into account. Crops that have the ability to quickly shade out weeds-particularly shrubby crop species with a dense crown such as $C$. cajan-should be favored in such timber-based agroforestry projects, as they can also reduce the use of herbicides and their associated impacts on human health and the environment (Vieira et al. 2009). C. cajan might also be of particular interest for agrisilvicultural systems due to the high profit margin found for this species in this study and its multiple uses as staple food crop, medicinal plant, fodder crop and N-fertilizer (Daniel and Ong 1990; Glover et al. 2012). Despite cassava's ineffectiveness in suppressing weeds and its low yields, intercropping trees with this crop still improved the NPV compared to pure forestry. This is an important finding, considering that reforestation is usually carried out on marginal agricultural sites. Our study provides data on tree species and crops that are abundant throughout the tropics and can serve as a basis for further research in other regions.

\section{Potential for adoption}

Garen et al. (2009) found that more than $40 \%$ of participants in reforestation projects in Panama intuitively mixed crops with trees. This proves that the potential for acceptance of this system is high. Nevertheless, the systematic and optimized application of it - particularly on a larger scale - is as yet unrealized. We argue that for smallholders of less than 10 ha (cf. Berdegué and Fuentealba 2011) who depend on their farms for their livelihoods, establishing such an agroforestry system to aid in the establishment of a tree plantation is not advisable, as it might put the family's food security at risk. It would only provide a productive alternative if the land were already degraded (Knoke et al. 2012). This system is designed to increase the attractiveness of reforestation as an investment for medium to large-scale land owners. The average farm size in Tortí is 85 ha (Schuchmann 2011). Dedicating marginal, often fallowed lands of such farms to an agrisilvicultural system could succeed in reintegrating them into the production circle and at the same time diversify farm products (Knoke et al. 2013).

Sixty percent of the up-front investment in pure forest plantations calculated 
here are pure input costs that cannot be covered by a farmer's labor. This share was $48 \%$ in the agroforestry system with maizebeans-maize and $36 \%$ for pure maize-beans-maize cultivation, respectively. For pure pigeon pea cultivation this share amounted to only $7 \%$. Depending on the financial resources of the landowner, this up-front investment might present a serious obstacle. Still, from year one on, input costs in the forest plantations decrease drastically, while pure agriculture entails annual expenses for seeds and fertilizer (in the case of maize). For other land owners, labor might be a more limited resource (Current et al. 1995). In commercial plantations, increasing day wages restrict the application of labor-intensive management options. The proposed intercropping approach can be adjusted to meet these individual preferences by selecting appropriate tree-crop combinations and by modifying planting densities - as has been demonstrate in Europe and North America (Graves et al. 2007; Cubbage et al. 2012). In larger-scale commercial tree plantations, the sudden decrease in work load after the first year often leads to suspension of workers. The simultaneous production of agricultural crops with less intensive management and flexible harvest dates (as e.g. pigeon pea) can help to increase labor efficiency and provide more constant employment in rural areas. For farmers who require a more constant income, a sequence of different timber-based agrisilvicultural systems, such as intercropping followed by shaded woody crops (e.g. coffee, cacao) (Vieira et al. 2009, Ewers 2013) and/or silvopastoral approaches (Cordero and Boshier 2003; Murgueitio et al. 2011) could be considered. Severe disincentives for any tree planting activities in Panama remain, including underdeveloped markets, the lack of market knowledge among farmers (Gó mez 1995; Fischer and Vasseur 2000) and complicated tree harvesting laws (Detlefsen and Scheelje 2012) which often force farmers to sell wood illegally at lower wood prices. The promotion and support of (often already existing) farmer's associations with the purpose of joint marketing of both forestry and agricultural products could improve this situation.

\section{Conclusions}

This study demonstrates the substantial economic advantage of product diversification for medium to large-scale forest plantations which - up to nowhas received scant attention in agroforestry research. We argue that if active reforestation is to be expanded in order to restore ecological services, the integration of crops into large-scale plantation systems might not only be vital to its competitiveness with the alternative - expansion of agricultural land-but also allow it to contribute to food security. Accordingly, further long-term systematic studies of timber-based agroforestry systems focusing on both biophysical and economic data are encouraged. 


\section{Acknowledgments}

This research was funded by the German Research Foundation (DFG) (Project WE 2069/6-1). C. Paul was supported by both the Elite Network of Bavaria and the program "Equal Opportunity for Women in Research and Teaching" at TUM. The authors are grateful to the Forest Finance Group for providing land and labor to the project and to BARCA SA for logistical help.

\section{References}

Akindele S, Onyekwelu J (2011) Review silviculture in secondary forests. In: Günter S, Weber M, Stimm B, Mosandl R (eds) Silviculture in the tropics, vol 8. Springer, Berlin Heidelberg, pp 351-367

ANAM (2010) Guía Técnica de la Reforestación en Panamá. (Manual for the Reforestation in Panama). Autoridad Nacional del Ambiente, Panama

ANAM (2011) Atlas Ambiental de la Republica de Panamá. Autoridad Nacional del Ambiente; Gobierno Nacional de la Rebú blica de Panamá, Panama

Berdegué JA, Fuentealba R (eds) (2011) Latin America: The state of smallholders in agriculture. Paper presented at the IFAD Conference on New Directions for Smallholder Agriculture 24-25 January, 2011

Bremer L, Farley K (2010) Does plantation forestry restore biodiversity or create green deserts? A synthesis of the effects of land-use transitions on plant species richness. Biodivers Conserv 19(14):3893-3915. doi:10.1007/s10531-010-99364

Buongiorno J, Gilless JK (2003) Decision methods for forest resource management. Academic Press, Amsterdam

Castro L, Calvas B, Hildebrandt P, Knoke T (2012) Avoiding the loss of shade coffee plantations: how to derive conservation payments for risk-averse land-users. Agrofor Syst 1-17. doi: 10.1007/s10457-012-9554-0

Ceccon E (2008) Production of bioenergy on small farms: a twoyear agroforestry experiment using Eucalyptus urophylla intercropped with rice and beans in Minas Gerais, Brazil. New For 35(3):285-298

Chamshama SAO, Monela GC, Sekiete KEA, Persson A (1992) Suitability of the taungya system at North Kilimanjaro forest plantation, Tanzania. Agrofor Syst 17(1):1-11. doi:10.1007/BF00122924

Chazdon R (2008) Beyond deforestation: restoring forests and ecosystem services on degraded lands. Science 320(5882): 1458-1460

Condit R, Sautu A (2001) Cultivo de Arboles Nativos de Panamá: Recolección, 
Germinació n, Viabilidad de Semillas y Crecimiento de Plántulas de ESpecies Poco Conocidas. Proyecto de Investigació n. Center for Tropical Forest Science, Panama City, Panama

Coomes OT, Grimard F, Potvin C, Sima P (2008) The fate of the tropical forest: carbon or cattle? Ecol Econ 65(2):207-212. doi:10.1016/j.ecolecon.2007.12.028

Cordero J, Boshier D (eds) (2003) Á rboles de Centroamérica: un Manual para Extensionistas (Trees of Central America: a Manual for Extentionists). Oxford Forestry Institute and CATIE (Centro Agronómico Tropical de Investigación y Enseñanza)

Craven D, Hall J, Verjans J (2009) Impacts of herbicide application and mechanical cleanings on growth and mortality of two timber Species in Saccharum spontaneum grasslands of the Panama canal watershed. Restor Ecol 17(6):751-761. doi:10.1111/j.1526-100X.2008.00408.x

Cubbage F, Koesbandana S, Mac Donagh P, Rubilar R, Balmelli G, Olmos VM, De La Torre R, Murara M, Hoeflich VA, Kotze H, Gonzalez R, Carrero O, Frey G, Adams T, Turner J, Lord R, Huang J, MacIntyre C, McGinley K, Abt R, Phillips R (2010) Global timber investments, wood costs, regulation, and $\begin{array}{llll}\text { risk. Biomass } & \end{array}$ doi:10.1016/j.biombioe.2010.05.008

Cubbage F, Glenn V, Paul Mueller J, Robison D, Myers R, Luginbuhl J, Myers R (2012) Early tree growth, crop yields and estimated returns for an agroforestry trial in Goldsboro, North Carolina. Agrofor Syst 86(3):323-334. doi:10.1007/ s10457-012-9481-0

Current D (1995) Economic and institutional analysis of projects promoting onfarm tree planting in Costa Rica. In: costs, benefits, and farmer adoption of agroforestry. Project experience in Central America and the Caribbean. World Bank-The World Bank Environment Paper, Washington, pp 45-80

Current D, Lutz E, Scherr S (1995) Costs, benefits, and farmer adoption of agroforestry. In: costs, benefits, and farmer adoption of agroforestry. Project experience in Central America and the Caribbean. World BankThe World Bank Environment Paper, Washington, pp 1-27

Daniel JN, Ong CK (1990) Perennial pigeonpea: a multi-purpose species for agroforestry systems. Agrofor Syst 10(2):113-129. doi:10.1007/BF00115360

Detlefsen G, Scheelje M (2012) Las normativas legales y el aprovechamiento de la madera en fincas. In: Detlefsen G, Somarriba E (eds) Producción de madera en sistemas agroforestales de Centroamérica. Centro Agronómico 
Tropical de Investigación y Ensenanza (CATIE), Turrialba, Costa Rica, pp 211-242

Ding S, Su P (2010) Effects of tree shading on maize crop within a Poplar-maize compound system in Hexi Corridor oasis, northwestern China. Agrofor Syst 80(1):117-129. doi: 10. 1007/s10457-010-9287-x

ETESA (2011) Historical data on mean annual temperature and rainfall in Tortí (1977-2011). http://www.hidromet.com. pa/clima_historicos.php Accessed on 13 February 2013

Evans J, Turnbull JW (2004) Plantation forestry in the tropics. The role, siviculture, and use of planted forests for industrial, social, environmental and agroforestry purposes, 3rd edn. Oxford Univ. Press, Oxford [u.a.]

Ewers L (2013) A Literature and interview based approach to identify less known understory species for the enrichment of different shade stages of agroforestry systems in Panama. Technische Universität München. http://mediatum. ub.tum.de/doc/1178390/1178390.pdf

FAO (2002) Teak (Tectona grandis) in Central America. Forest plantations working papers, FP/19. Food and Agriculture Organization of the United Nations (FAO), Rome

Fischer A, Vasseur L (2000) The crisis in shifting cultivation practices and the promise of agroforestry: a review of the Panamanian experience. Biodivers Conserv 9(6):739-756 ForestFinance (2012) Inventory data provided by ForestFinance group. Panama city. Panama

Franzel S (2005) Financial analysis of agroforestry practices: fodder shrubs in Kenya, woodlots in Tanzania, and improved fallows in Zambia. In: Alavalapati JR, Mercer DE (eds) Valuing agroforestry systems. Springer Business Media Inc, New York, pp 9-37

Friday JB, Fownes JH (2002) Competition for light between hedgerows and maize in an alley cropping system in Hawaii, USA. Agrofor Syst 55(2):125-137. doi: 10.1023/ A\%3A1020598110484

Garen E, Saltonstall K, Slusser J, Mathias S, Ashton M, Hall J (2009) An evaluation of farmers' experiences planting native trees in rural Panama: implications for reforestation with native species in agricultural landscapes. Agrofor Syst 76(1):219-236

Glover JD, Reganold JP, Cox CM (2012) Agriculture: plant perennials to save Africa's soils. Nature 489(7416):359-361. doi:10.1038/489359a

Goers L, Lawson J, Garen E (2012) Economic drivers of tropical deforestation for agriculture. In: Ashton MS, Tyrrell ML, Spalding D, Gentry B (eds) Managing forest carbon in a changing climate. Springer, Netherlands, pp 
$305-320$

Gómez M (1995) Economic and institutional analysis of agro-forestry projects in Panama. In: Costs, benefits, and farmer adoption of agroforestry. Project Experience in Central America and the Caribbean. World Bank-The World bank environment paper, Washington, pp 146-162

Graves AR, Burgess PJ, Palma JHN, Herzog F, Moreno G, Bertomeu M, Dupraz C, Liagre F, Keesman K, van der Werf W, de Nooy AK, Van den Briel JP (2007) Development and application of bio-economic modelling to compare silvoarable, arable, and forestry systems in three European countries. Ecol Eng 29(4):434-449. doi:10.1016/ j.ecoleng.2006.09.018

Griess VC, Knoke T (2011) Can native tree species plantations in Panama compete with Teak plantations? An economic estimation. N Forests 41(1):13-39. doi:10.1007/s11056- 010-9207-y

Griscom HP, Ashton MS (2011) Restoration of dry tropical forests in Central America: a review of pattern and process. The ecology and ecosystem services of native trees: implications for reforestation and land restoration in Mesoamerica. For Ecol Manag 261(10):1564-1579. doi: 10.1016/j.foreco.2010.08.027

Günter S, Weber M, Erreis R, Aguirre N (2007) Influence of distance to forest edges on natural regeneration of abandoned pastures: a case study in the tropical mountain rain forest of Southern Ecuador. Eur J For Res 126(1):67-75. doi:10.1007/s10342-006-0156-0

Günter S, Cabrera O, Weber M, Stimm B, Zimmermann M, Fiedler K, Knuth J, Boy J, Wilcke W, Iost S, Makeschin F, Werner F, Gradstein SR, Mosandl R (2008) Natural forest management in neotropical mountain rain forests - an ecological experiment. In: Beck E, Bendix J, Kottke I, Makeschin F, Mosandl R, Caldwell MM, Heldmaier G, Jackson RB, Lange OL, Mooney HA, Schulze E, Sommer U (eds) Gradients in a tropical mountain ecosystem of Ecuador, vol 198. Springer, Berlin Heidelberg, pp 347-359

Haggar J, Rheingans R, Arroyo P, Alvarado B (2003) Benefits and costs of intercropping reforestation in the Atlantic lowlands of Costa Rica. N For 25(1):41-48

Hänsela G, Ibrahimb M, Villanuevab C, Andrade H (2009) Expoliting synergies between silvopastoral system components for carbon sequestration and an increase in cattle productivity: experience from Costa Rica and Nicaragua. XIII World Forestry Congress, 18-23 October 2009, Buenos Aires, Argentina

Hazlett DMJ (1980) El crecimiento de 27 especies maderables en plantaciones de Lancetilla, Honduras. Report. Escuela Nacional de Sciencias Forestales, 
Honduras

IDIAP (2006) Zonificación de suelos de Panamá por niveles de nutrientes. Instituto de Investigació nAgropecuaria de Panamá. http://bdigital.binal.ac.pa/bdp/descarga.php?f=idiap1. pdf. Accessed March 2014

INEC (2011) VII Censo Nacional Agropecuario 2011. Resultados Finales Básicos. Instituto Nacional de Estadística y Censo, Contraloría General de la República de Panamá

IUCN (2012) IUCN Red List of Threatened Species. Version 2012.2. http://www.iucnredlist.org/technicaldocuments/ red-list-documents. Accessed March 2014

Jordan CF (ed) (1992) Taungya. Forest plantations with agriculture in Southeast Asia. CAB International, Wallingford

Jose S (2009) Agroforestry for ecosystem services and environmental benefits: an overview. Agrofor Syst 76(1):1-10. doi:10.1007/s10457-009-9229-7

Kalame FB, Aidoo R, Nkem J, Ajayie OC, Kanninen M, Luukkanen O, Idinoba M (2011) Modified taungya system in Ghana: a win-win practice for forestry and adaptation to climate change? Environ Sci Policy 14(5):519-530. doi:10. 1016/j.envsci.2011.03.011

Kanninen M, Pérez D, Montero M, Víquez E (2004) Intensity and timing of the first thinning of Tectona grandis plantations in Costa Rica: results of a thinning trial. For Ecol Manag 203(1-3):89-99

Kapp G, Beer J (1995) A comparison of agrisilvicultural systems with plantation forestry in the Atlantic lowlands of Costa Rica. Agrofor Syst 32:207-223

Knoke T, Calvas B, Aguirre N, Roman-Cuesta RM, Günter S, Stimm B, Weber M, Mosandl R (2009) Can tropical farmers reconcile subsistence needs with forest conservation? Front Ecol Environ 7(10):548-554

Knoke T, Román-Cuesta RM, Weber M, Haber W (2012) How can climate policy benefit from comprehensive land-use approaches? Front Ecol Environ 10(8):438-445. doi:10. 1890/110203

Knoke T, Calvas B, Moreno SO, Onyekwelu JC, Griess VC (2013) Food production and climate protection-What abandoned lands can do to preserve natural forests. Glob Environ Change 23(5):1064-1072. doi:10.1016/j.gloenvcha.2013.07.004

Kreuzer S (2013) Untersuchungen zur Konkurrenz sowie zur Interaktion zwischen Cajanus Cajan und sechs verschiedenen tropischen Wertholzarten in Panama. Master Thesis, Technische Universität München 
Lamb A (1968) Cedrela odorata. Fast growing timber trees of the lowland tropics, vol 2. Commonwealth Forestry Institute, Oxford

Love B, Spaner D (2005) A survey of small-scale farmers using trees in pastures in Herrera Province, Panama. J Sustain For 20(3):37-65

Maraseni T, Cockfield G, Cadman T, Chen G, Qu J (2012) Enhancing the value of multiple use plantations: a case study from southeast Queensland, Australia. Agrofor Syst 86(3):451-462. doi:10.1007/s 10457-012-9506-8

Martin FS, van Noordwijk M (2011) Is native timber tree intercropping an economically feasible alternative for smallholder farmers in the Philippines? Aust J Agric Resour Econ 55(2):257-272. doi:10.1111/j.14678489.2011. 00530.x

Mayhew JE, Newton AC (1998) The silviculture of mahogany. CABI Pub, Wallingford

MIDA (2011) Costo de Produccion Ano Agricola 2010-2011. Ministry of Agricultural Development. http://www.ima. gob.pa. Accessed 15 November 2012

Montagnini F, Ugalde L, Navarro C (2003) Growth characteristics of some native tree species used in silvopastoral systems in the humid lowlands of Costa Rica. Agrofor Syst 59(2):163-170. doi: 10.1023/A:1026351812036

Montero M. M, Kanninen M (2005) Terminalia amazonia. Ecología y silvicultura. Serie Técnica, Informe Técnico no. 339. CATIE, Turrialba, Costa Rica

Murgueitio E, Calle Z, Uribe F, Calle A, Solorio B (2011) Native trees and shrubs for the productive rehabilitation of tropical cattle ranching lands. For Ecol Manag 261(10): 1654-1663. doi:10.1016/j.foreco.2010.09.027

ONF (2012) Precios de la madera para el I Trimestre del 2012. Oficina Nacional Forestal de Costa Rica (ONF). http:// www.ofi .org/publicacionestecnicas-onf/ precios-de-la-madera. Accessed November 2012

Palomeque FP (2012) Natural succession and tree plantation as alternatives for restoring abandoned lands in the Andes of Southern Ecuador: aspects of facilitation and competition. Dissertation, Technische Universität Mü nchen

Paul C (2014) Timber-based agrisilvicultural systems to facilitate reforestation in Panama - a silvicultural and economic evaluation. Dissertation. Technische Universitat Munchen

Paul C, Weber M (2013) Intercropping cedrela odorata with shrubby crop species to reduce infestation with Hypsipyla grandella and improve the quality of timber. ISRN Forestry 10. doi: 10.1155/2013/637410

Pearce D, Putz FE, Vanclay JK (2003) Sustainable forestry in the tropics: panacea 
or folly? For Ecol Manag 172(2-3): 229-247. doi:10.1016/S03781127(01)00798-8

Pérez D, Kanninen M (2005) Stand growth scenarios for Tectona grandis plantations in Costa Rica. For Ecol Manag 210(1-3):425-441

Piotto D, Montagnini F, Ugalde L, Kanninen M (2003) Performance of forest plantations in small and mediumsized farms in the Atlantic lowlands of Costa Rica. For Ecol Manag 175(1-3):195-204

Piotto D, Víquez E, Montagnini F, Kanninen M (2004) Pure and mixed forest plantations with native species of the dry tropics of Costa Rica: a comparison of growth and productivity. For Ecol Manag 190(2-3):359372. doi:10. 1016/j.foreco.2003.11.005

Piotto D, Craven D, Montagnini F, Alice F (2010) Silvicultural and economic aspects of pure and mixed native tree species plantations on degraded pasturelands in humid Costa Rica. N For 39:369-385

Redondo-Brenes A, Montagnini F (2006) Growth, productivity, aboveground biomass, and carbon sequestration of pure and mixed native tree plantations in the Caribbean lowlands of Costa Rica. For Ecol Manag 232(1-3):168-178. doi:10.1016/j.foreco.2006.05.067

Reid WVC (2005) Ecosystems and human well-being. General synthesis: a report of the Millennium ecosystem assessment. Island Press, Washington

Sands R (2005) Forestry in a global context. CABI Pub, Wallingford

Schlönvoigt A, Beer J (2001) Initial growth of pioneer timber tree species in a Taungya system in the humid lowlands of Costa Rica. Agrofor Syst 51(2):97-108. doi:10.1023/A: 1010674402907

Schuchmann J (2011) A participatory survey on current integration of trees on farms and pastures within land use systems in the township of Tortí in Panama. Bachelor Thesis, Technische Universität Mü nchen

Sloan S (2008) Reforestation amidst deforestation: simultaneity and succession. Globalisation and environmental governance: is another world possible? Glob Environ Change 18(3):425-441

Swallow SK, Parks PJ, Wear DN (1990) Policy-relevant nonconvexities in the production of multiple forest benefits. J Environ Econ Manag 19(3):264280

Tilman D, Cassman KG, Matson PA, Naylor R, Polasky S (2002) Agricultural sustainability and intensive production practices. Nature 418(6898):671677. doi:10.1038/nature01014 Tschakert P, Coomes OT, Potvin C (2007) Indigenous livelihoods, slash-and-burn agriculture, and carbon stocks in 
Eastern Panama. Ecol Econ 60(4):807-820

Vieira DLM, Holl KD, Peneireiro FM (2009) Agro-successional restoration as a strategy to facilitate tropical forest recovery. Restor Ecol 17(4):451-459. doi:10.1111/j.1526-100X. 2009.00570.x

Wadsworth F (ed) (1960) Datos de crecimiento de plantaciones forestales en México, Indias Occidentales y Centro y Sur América. Carribean Forester 21

Waltenberger W (2013) Characterization of crown structures and light conditions in stands of six different tree species along a gradient of age and planting distance in Panama and their relevance for agroforestry systems. Master Thesis, Technische Universität München

Watanabe H (1992) Tree-crop interactions in Taungya Plantations. In: Jordan CF (ed) Taungya. Forest plantations with agriculture in Southeast Asia. CAB International, Wallingford, pp 32-43

Whitmore JL (1978) Cedrela provenance trial in Puerto Rico and St. Croix; establishment phase. USDA Forest Service, Research Note ITF-16. Institute of Tropical Forestry, Rio Piedras, Puerto Rico

Witcomb M, Dorward P (2009) An assessment of the benefits and limitations of the shamba agroforestry system in Kenya and of management and policy requirements for its successful and sustainable reintroduction. Agrofor Syst 75(3): 261-274. doi:10.1007/s10457-008-9200-Z 